\title{
Green issues dominate election
}

\section{VANCOUVER}

As the United States heads for a showdown at the polls, its Canadian neighbour is rushing out its own election - announced on 7 September, voting is scheduled for 14 October. In Canada, a country dominated by vast expanses of wilderness - as well as growing greenhouse-gas emissions - green issues are at the forefront of the debate.

"In many ways this is the first time that this has happened in Canadian history - the first environment election and the first climate election," says Graham Saul, executive director of the non-partisan Climate Action

\section{"Canadian politicians don't like to make a stand if Americans aren't doing the same."}

features in the party's television advertisements. A quote from Al Gore - "We should tax what we burn, not what we earn" - is prominent on the Green Shift website.

Harper was elected in 2006 after a decade of Liberal leadership. The most recent polls show that the Conservatives are ahead in this year's race, in which they hope to win a majority government.

The focus on green issues is exemplified by a row over the Green party's participation in televised debates scheduled for the first week of October. Despite having a member of parliament and more than $5 \%$ support in polls (the usual criteria for

Prime Minister Stephen Harper, the leader of Canada's minority Conservative (centre-right) government, has so far campaigned on his ability to manage the economy. Opposing Liberal (centre-left) party leader Stéphane Dion's defining policy is the 'Green Shift', a plan to shift taxes away from income and investment and towards pollution and greenhouse-gas emissions. Dion has attacked the Conservative party's environmental inaction, including its abandonment of Kyoto Protocol targets in 2006. He even has a dog named Kyoto, which

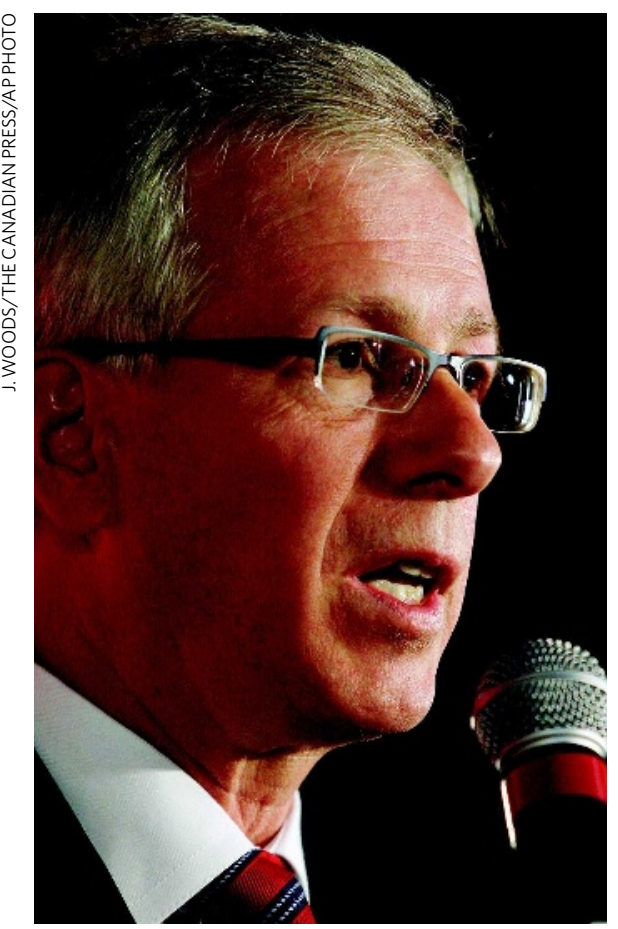

Liberal leader Stéphane Dion's election campaign focuses on green issues. participating in the event), when Green leader Elizabeth May asked for her invitation, Harper threatened to boycott the event if she attended. "Ms May is basically presenting the same positions as Mr Dion," complained Harper, saying that would make the event unfair. This ignited a storm of controversy and drew pointed remarks about Harper's apparent unwillingness to be questioned on his environmental policies. Under pressure, Harper reversed his position and last week May was invited onto the show.

It was a busy week. On 9 September, four former prime ministers - two Conservative and two Liberal - signed the Canadians for Climate Leadership Declaration. The document is a general call for action without many specifics, but it does make a key point that pricing carbon - they support Can $\$ 30$ (US\$28) per tonne $\mathrm{CO}_{2}$ equivalent - is an essential part of tackling climate change.

\section{High emissions}

Canada was one of the first countries to sign the Kyoto Protocol in 1998, pledging to reduce emissions by $6 \%$ below 1990 baseline levels by 2012. But emissions were more than $20 \%$ over baseline when the Conservatives took power in 2006, just before they admitted that Kyoto targets wouldn't be met. Today Canada's per capita emissions and energy consumption are among the highest in the world. Rapid population growth and rising export markets make national emission targets - rather than per capita targets - hard to meet, notes economist and policy expert Thomas Courchene of Queen's University in Kingston, Ontario. The country also has strong commercial interests in fishing, forestry, trucking and oil, including Alberta's tar-sand oil refineries, which can make environmental policies hard to push through.

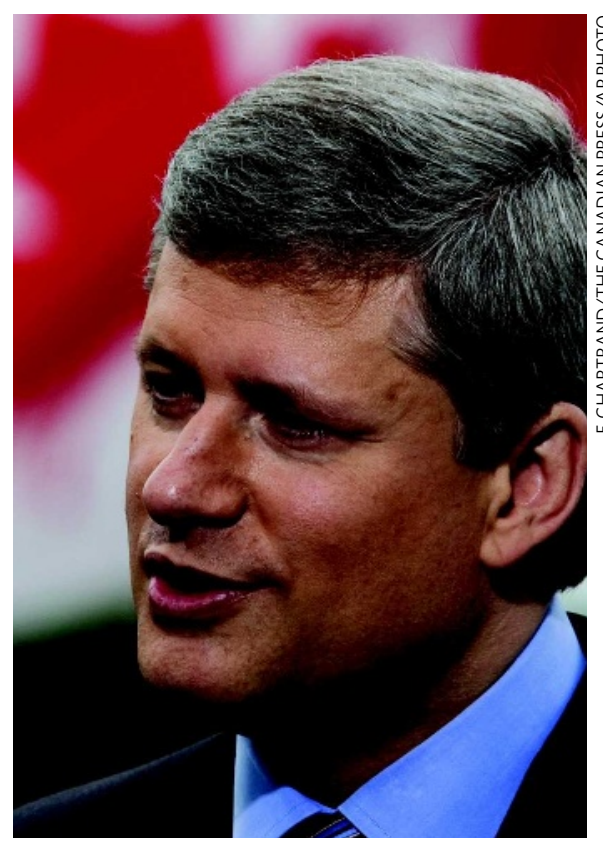

Conservative leader Stephen Harper puts the economy high on his agenda.

The Green Shift's main promise is to tax greenhouse-gas emissions, starting at Can $\$ 10$ per tonne of $\mathrm{CO}_{2}$ and reaching Can $\$ 40$ per tonne within four years. This would be matched by reductions in income tax, making the plan revenue neutral. Existing taxes on gasoline mean that the plan shouldn't hit pump prices, and there will be no price hikes for diesel and aviation fuel for the first year. "It will mean huge price increases for coal, and increased interest in clean coal," says Courchene. Harper has promised to cut diesel taxes.

The Conservatives don't dispute that climate change is important, but argue over the way to tackle it. Their policies include cutting emissions to $20 \%$ below 2006 levels by 2020 , requiring carbon capture and storage for Alberta tar-sand operations that start after 2012, and starting an emissions-trading plan based on national energy efficiency, using energy intensity - the amount of energy per unit of gross domestic product - rather than absolute caps.

The Liberal party aims for a $20 \%$ emissions cut below 1990 levels by 2020. And it has plans for a cap-and-trade programme, as exists in Europe, but acknowledges it will take years to set up the bureaucracy to support it; a tax can be implemented immediately. The main point emphasized by the declaration of former prime ministers, advocacy groups and all the main Canadian parties aside from the Conservatives, 
says Saul, is to put a price on carbon quickly.

A small foray into carbon taxing has already been made in Canada. British Columbia's Liberal provincial government implemented the first major North American carbon tax in July, at a rate of Can $\$ 10$ per tonne of $\mathrm{CO}_{2}$ (or equivalent emissions), rising to Can $\$ 30$ per tonne in 2012. The province's plan is also revenue neutral, with companies paying the majority of the tax and individuals receiving most of the credit including a one-off cheque for Can $\$ 100$ earlier this summer that is meant to be spent on creating more environmentally friendly lifestyles.

Earlier this month, more than $60 \%$ of 1,000 people polled nationally said that climate change would be important or the most important issue in deciding their vote. Such opinions don't always survive in the polling booth, but constant reminders of the impacts of climate change did influence Conservative-minded Australians to vote out their government in elections last year.

Canadian policy experts see their country lagging behind Europe on climate issues. It could yet catch up. But although Canada's election precedes the one down south, their policies may yet be held back by US decisions. "There's a real danger that we're just going to kind of adopt whatever happens in the United States," says Saul. "Canadian politicians don't like to make a stand if Americans aren't doing the same."

Nicola Jones

See Editorial, page 263.

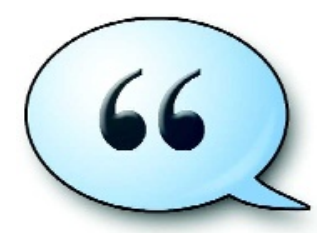

HAVE YOUR SAY

Comment on any of our

News stories, online.

www.nature.com/news

\section{Iran holds AIDS doctors}

Iran is under mounting pressure to reveal the whereabouts of two of the nation's HIV researchers, who have been detained without charge since late June.

The brothers, Arash and Kamiar Alaei, have achieved international acclaim for their progressive HIV-prevention programme and were scheduled to speak about it at the 17th International AIDS Conference in Mexico City last month. Both were arrested before leaving the country. The men had collaborated with other scientists around the world, including some in the United States, and are not thought to have been politically active.

Protests in their support were made at the conference. Since then, several human-rights organizations, including Physicians for Human Rights and Amnesty International, have called

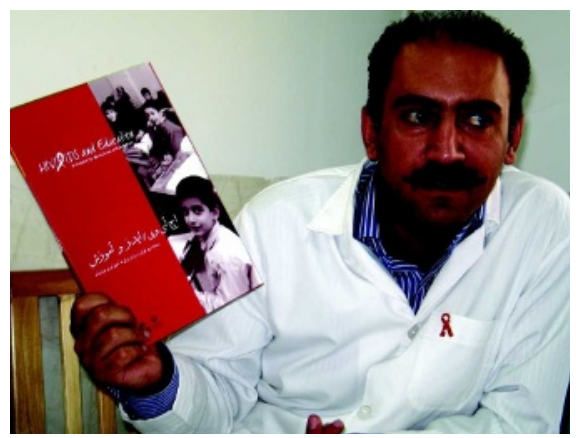

Arash Alaei has not been seen since June. on Iran to abide by its international legal obligations to explain the arrests and allow the men access to lawyers and the right to contest their detention before a judge.

The call has been taken up by several scientific bodies, including the International AIDS Society, the Foundation for AIDS Research and the American Association for the Advancement of Science (AAAS), and thousands of scientists and physicians have signed an online petition at www. iranfreethedocs.org. Barry Bloom, dean of the Harvard School of Public Health in Boston, Massachusetts, has also expressed his "deep concern" over the brothers' detention.

Kamiar, the younger of the brothers, holds a master's degree from the Harvard School of Public Health and was to have resumed doctoral studies at the University of Albany's School of Public Health in New York. Arash, former head of international education and research cooperation at the Iranian National Research Institute of Tuberculosis and Lung Disease, runs a clinic in Tehran.

HIV is a taboo subject in much of the Middle East, including Iran, but the brothers have helped to forge impressive prevention and treatment programmes - the country is now one of the few to distribute condoms and syringes in prisons, for example.

Declan Butler

\section{Japan fast-tracks stem-cell patent}

Kyoto University in Japan has acquired the world's first patent for induced pluripotent stem (iPS) cells. The university paid registration fees for the patent (2008-131577), which is of only limited coverage and applies only in Japan, on 2 September, after it was approved by the Japanese patent office.

Shinya Yamanaka, a stem-cell researcher at the university, created the first iPS cells in 2006 by using four genetic factors to 'reprogram' adult cells from mice into an embryonic-stem-cell-like state. A year later he achieved the same in human cells, publishing the research the same day as a US team led by James Thomson of the University of Wisconsin. Thomson's group used a different set of genetic factors to make its human iPS cells.
iPS cells have the potential to develop into almost any of the body's cell types, and hold great promise in therapy and disease modelling. Kyoto University applied for an international patent (PCT/ JP2006/324881) in December 2006. A US patent application is in Yamanaka's name.

Kyoto University expects the international patent to cover iPS cells from all species - "any cell, besides a germ cell, of any type of organism," says Hideya Hayashi of the university's iPS Cell Research and Application office.

The international patent has many claims in it, so it will probably take another year or longer for the various patent offices to process and approve it, says Hayashi. Kyoto University did not want to wait, so it fast-tracked the Japanese patent application for the most basic claim, covering the "method" of using Yamanaka's four genetic factors to reprogram a cell. "A lot of people were wondering what was happening with these patents. We wanted to make it clear," Hayashi says.

Other claims in the international patent still need to be worked out, especially that covering the product, the iPS cells themselves. It's not certain whether Yamanaka's patents cover iPS cells created by reprogramming with different genetic factors. Itsuki Shimbo, a patent attorney with the Tokyobased firm Tsubame says it is unclear whether the patent will be able to restrict scientists using other combinations.
Hayashi says the university does not plan to restrict others from doing iPS cell research. Rather, it wants to ensure that people, including Yamanaka, are not restricted by other patents and can freely use iPS cell technology. "We want to remove any potential obstacles to the quick clinical application of iPS technology," Hayashi says. "We are not trying to confine its use."

Shimbo says that Yamanaka's patent might prevent future restrictive iPS patents based on different combinations of genetic factors. "It will be very hard to claim that such a change was truly novel," he says.

The Japanese patent will be valid until 6 December 2026, 20 years from the application date.

David Cyranoski 